УДК 658.1

DOI: https://doi.org/10.26642/jen-2020-1(91)-75-80

\author{
Г.М. Тарасюк, д.е.н., проф. \\ О.А. Донець, магістрант \\ Л.О. Горшкова, ст. викладач \\ Державний університет «Житомирська політехніка»
}

\title{
Стратегічні карти показників як інструмент управлінської практики
}

\begin{abstract}
У статті розглянуто теоретичні засади формування стратегічних карт показників та визначено їх значення для забезпечення реалізачії стратегї будь-якої організації. Проведено аналіз існуючих збалансованих систем показників, які досліджено провідними вченими та використовуються у практиці господарювання. В статті доведено важливість взаємозв'язку системи показників за різними рівнями ієрархї. Доведено, щуо узгодженість між різними показниками визначається характером причинно-наслідкових зв'язків, досягається шляхом гармонізачї̈, збалансованості та координації визначень і класифікацій, які покладені в основу їх розрахунку. Знання змісту показників $i$ форм зв'язків між ними дозволять створити багатогранне відображення сукупності прочесів, які плануються в господарській діяльності. Окрім того, збалансована система показників виконує певні функиї (планову, контрольну, стимулюючу, регулюючу). Розглянуто особливості формування стратегічних карт показників для державних установ та організаџій. Також наведено укрупнену модель збалансованої системи показників планування потенціалу виробничого підприємства.
\end{abstract}

Ключові слова: управління; стратегічні карти; показники; збалансована система показників; ієрархія; стратегія; план; інструмент управління.

Постановка проблеми в загальному вигляді та ії зв'язок із практичними завданнями. Менеджерам сучасного бізнесу та державного управління потрібне розуміння фундаментальної логіки організацій, у яких вони працюють. Керуючись розумінням організаційної стратегії, можна ефективно працювати в інтересах своєї компанії. Користь від збалансованої системи показників (далі ЗСП) як форми карт показників полягає в мобілізації потенціалу організації задля стратегічного мислення, а також фокусування на реалізації розробленої стратегії. У зарубіжній практиці господарювання широко застосовують стратегічні карти показників, які $\epsilon$ інструментом управління стратегічним розвитком підприємства, оскільки добре сформульована карта показників відображає стратегічну логіку причиннонаслідкових зв'язків між поточною діяльністю та довгостроковим успіхом. Виходячи 3 аналізу зарубіжних систем показників, які застосовуються в управлінні діяльністю підприємств, відповідно до інформаційних потреб користувачів управлінської інформації, для вітчизняних підприємств варто розглянути систему збалансованих показників підприємства, яка б відповідала особливостям сучасних умов господарювання, враховувала міжнародний досвід та міжнародні стандарти менеджменту, стала інструментом підвищення ефективності господарювання та була направлена на реалізацію інтересів усіх зацікавлених сторін, забезпечуючи підприємству високий рейтинг корпоративної соціальної відповідальності в суспільстві.

Аналіз останніх досліджень та публікацій. Збалансована система показників належить до інструментів та організаційних процесів, у яких використовуються прості, перевірені у використанні формати для забезпечення багатостороннього, детального опису того, що і чому робить організація. Збалансовану систему планових показників варто використовувати в управлінні діяльністю організації у напрямі досягнення стратегічних цілей діяльності, проведення постійного моніторингу і контролю, щоб вчасно приймати адекватні управлінські рішення. Класична модель ЗСП у межах концепції Роберта Каплана та Девіда Нортона використовується багатьма зарубіжними фірмами в різних варіантах: як схема для обговорення стратегії; як інструмент управління та організації звітності в межах чотирьох або п'яти перспектив, які виокремлені в ЗСП; вводяться на заміну бюджетів як поєднання ЗСП і оперативних планів руху грошових коштів; як інструмент управління на ієрархічних рівнях від ЗСП фірми до системи показників окремих виконавців; як карти показників для окремих проектів; як інструмент виконання корпоративних функцій управління в інформаційних технологіях (IT) або при управлінні людськими ресурсами тощо [1-9]. Зростає актуальність ЗСП для уряду та інших некомерційних підприємств [10]. Це ще раз підтверджує, що ЗСП може застосовуватися для управління будь-якою сферою діяльності. Тому може існувати загальний формат цієї системи, але для кожної сфери діяльності, кожного суб'єкта господарювання він визначатиметься індивідуально, залежно від особливостей бізнесу.

Теоретичними і методичними проблемами формування та обгрунтуванням доцільності впровадження ЗСП в практику господарювання в різний час займалися такі відомі зарубіжні й вітчизняні вчені, як: Нільс-Горан Олве, Карл-Йохан Петрі, Жан Рой, Софі Рой, Роберт Каплан, Девід Нортон, А.С. Воронкова, 
М.О. Кизим, С.О. Хайлук та інші. Проте, не дивлячись на велику кількість фундаментальних праць і прикладних робіт, $є$ цілий ряд питань, які потрібно досліджувати. Зокрема питання формування стратегічних карт показників, їх узгодженості, взаємодії, контролю, вбудовування у систему мотивації тощо.

Метою статті $\epsilon$ дослідження теоретичних та методичних питань розробки стратегічних карт показників, а також визначення важливості їх впровадження в діяльність суб'єктів господарювання.

Викладення основного матеріалу дослідження. Складність оцінки діапазону використання стратегічних карт показників пов'язана 3 тим, що розуміють під терміном «використання». У деяких дослідженнях половина респондентів заявляє, що їхні компанії збираються використовувати ЗСП у найближчому майбутньому або вже використовують. Професор М.О. Кизим з позицій системного підходу обгрунтував принципи побудови й методологію впровадження концепції ЗСП Р.Каплана та Д.Нортона і визначив можливості iї застосування для створення синергії і стратегічної єдності інтегрованих об’єднань підприємств [11]. Проте, не дивлячись на значний позитив зазначеної концепції, обов'язково варто враховувати певні їі недоліки та обмеження. Тільки при їх врахуванні можна приймати рішення про доречність її практичного застосування. Основними недоліками та обмеженнями ЗСП є:

вибір стратегічних дій у ЗСП описаний авторами не точно й призводить на практиці до серйозних проблем;

- через велику кількість зв'язків, не завжди причинно-наслідкових, ступінь впровадження ЗСП надмірно високий;

внаслідок відсутності системного процесу планування та управління ним на підприємствах, перспективи можуть розподілятися, виходячи із уподобань менеджерів, які прагнуть врахувати інтереси груп зацікавлених сторін різної впливовості й значення;для ЗСП характерний лише лінійний характер зв'язків та співвідношень між показниками в різних перспективах;

визначені перспективи в межах чотирьох аспектів надмірно спрощують стратегію і надзвичайно складно в таких умовах, забезпечити відповідність усіх сфер діяльності базовим вимогам концепції тощо [1].

Кожна організація створює унікальну стратегію, базуючись на власній інтерпретації зовнішнього та внутрішнього середовища. Звичайно, на карті показників може відображатися комбінація декількох напрямів діяльності організації. Але щоб довести стратегічні карти до кінцевого використання в організації, потрібно їх розробляти відповідно до узгоджених цілей та планів діяльності. Окрім того, обговорення стратегій та цілей варто проводити у всіх підрозділах і на всіх корпоративних рівнях. Тоді стратегічні карти не тільки відображатимуть бізнес-логіку, але й будуть зрозумілі менеджерам усіх рівнів.

Хайлук С.О. рекомендує застосовувати систему збалансованих показників в управлінні молокопереробним холдингом, зазначаючи, що ключовою особливістю системи управління холдингом на основі цієї системи є зв'язок усіх їі показників з фінансовими результатами діяльності, не враховуючи інших стратегічних цілей діяльності й тим самим звужуючи межі цієї системи лише до фінансових цілей [11].

До факторів, що забезпечують успіх впровадження ЗСП, варто зарахувати обов'язкову наявність ефективно функціонуючої системи планування і контролю на підприємстві в межах концепції планування потенціалу підприємств, яка передбачає системний процес управління підприємством, направлений на досягнення стратегічних цілей діяльності та задоволення інтересів усіх зацікавлених сторін [1].

На нашу думку, ЗСП є цінним інструментом, який дозволить працівникам зрозуміти, де організація сьогодні та, головне, куди вона йде. ЗСП також забезпечує менеджмент системною інформацією в процесі розробки та документування показників, які швидше приведуть до досягнення стратегічних цілей.

Збалансована система планових показників - це сукупність взаємопов'язаних взаємозбалансованих показників-характеристик (параметрів) майбутнього стану підприємства, які відображають характеристики об'єктів планування, $\epsilon$ індикаторами розвитку підприємства та їх структурних підрозділів і окремих виконавців, розкривають характер взаємовідносин, що формуються в процесі складання планів та їх реалізації в межах загальної стратегії розвитку та наявного потенціалу [13, с. 101].

Взаємозв'язок показників, логічне поєднання одних показників 3 іншими - це обов'язкова риса системи показників, яка претендує на те, щоб бути саме системою, а не набором більш-менш цікавих, актуальних та необхідних показників. Збалансована система показників є орієнтиром на задоволення інтересів усіх стейкхолдерів підприємства чи організації.

Збалансована система планових показників є діалектичним цілим, у якому всі показники займають відповідне місце і є скоординованими. Узгодженість між різними показниками визначається характером причинно-наслідкових зв'язків, досягається шляхом гармонізації, збалансованості та координації визначень і класифікацій, які покладені в основу їх розрахунку. Знання змісту показників і форм зв'язків між ними дозволять створити багатогранне відображення сукупності процесів, які плануються в господарській діяльності. Окрім того, збалансована система показників виконує певні функції [15, с. 142].

Управлінська функція збалансованої системи планових показників полягає в тому, що ця система охоплює всі рівні управління, які взаємопов'язані між собою та мають характер причинно-наслідкового зв'язку. Користувачами планової інформації (планових показників) є менеджери різних рівнів управління та виконавці планів, що мають свої орієнтири діяльності (рис. 1). 


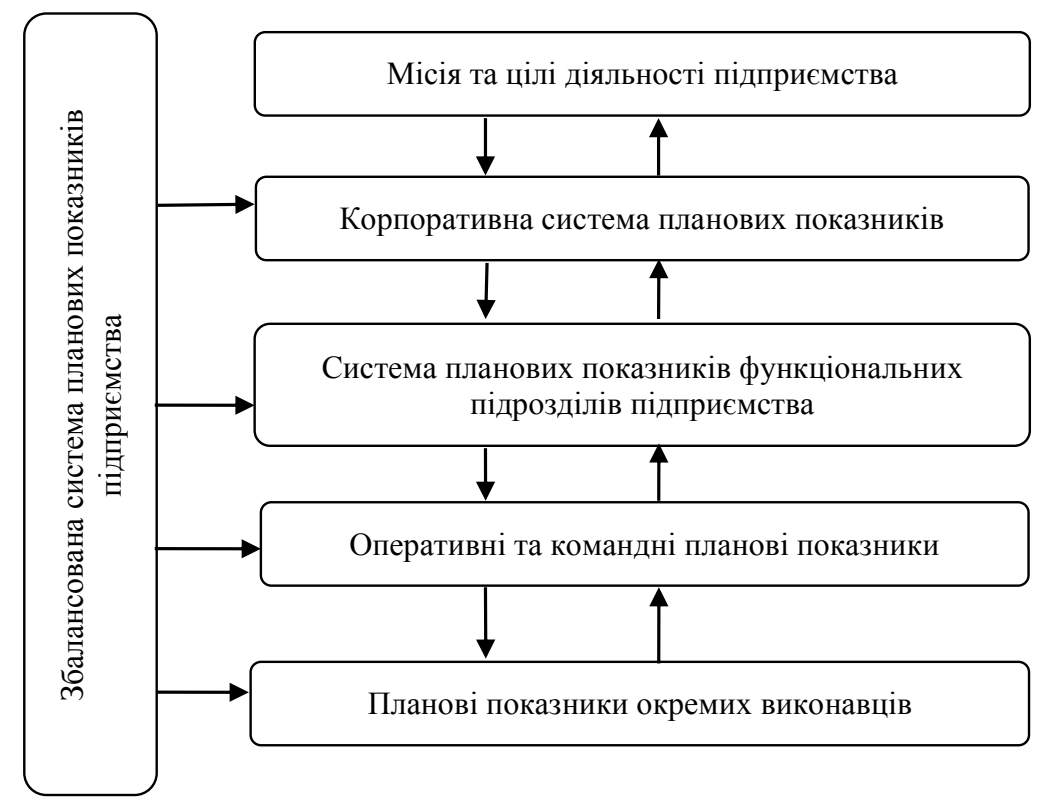

Рис. 1. Збалансована система планових показників за ієрархічними рівнями управління [14, с. 177]

Аналіз функцій планування й адміністративного управління показує, що недоліки в управлінні зводяться до використання невідповідного цілям діяльності інструментарію (показників, а особливо норм та нормативів), що визначають плановий і фактичний стан об'єкта, або ж трапляються помилки при розрахунках, у результаті чого порушується принцип точності та системності в плануванні [16, с. 142].

Контрольна функція збалансованої системи показників полягає в тому, що саме вони є нормативним значенням, еталоном для проведення контролю за виконанням поставлених планів і завдань. Контрольна функція показників як інструменту управління забезпечує всі ієрархічні рівні управління інформацією про стан досягнення планових результатів, про рівень та якість виконання планів, ступінь їх напруженості [16, с. 142].

Стимулююча функція планових показників полягає у тому, що при досягненні рівня запланованих показників, при якісному виконанні планів, кожен учасник планування отримує винагороду за їх виконання, яка передбачена системою мотивації планової діяльності; успішне виконання планів в цілому по підприємству стимулює власників та менеджерів підприємства до нарощування потенціалу та покращення майбутніх результатів діяльності, визначення майбутніх цілей розвитку тощо [16, с. 142].

У межах концепції планування потенціалу підприємства збалансовану систему планових показників можна зобразити таким чином (рис. 2):

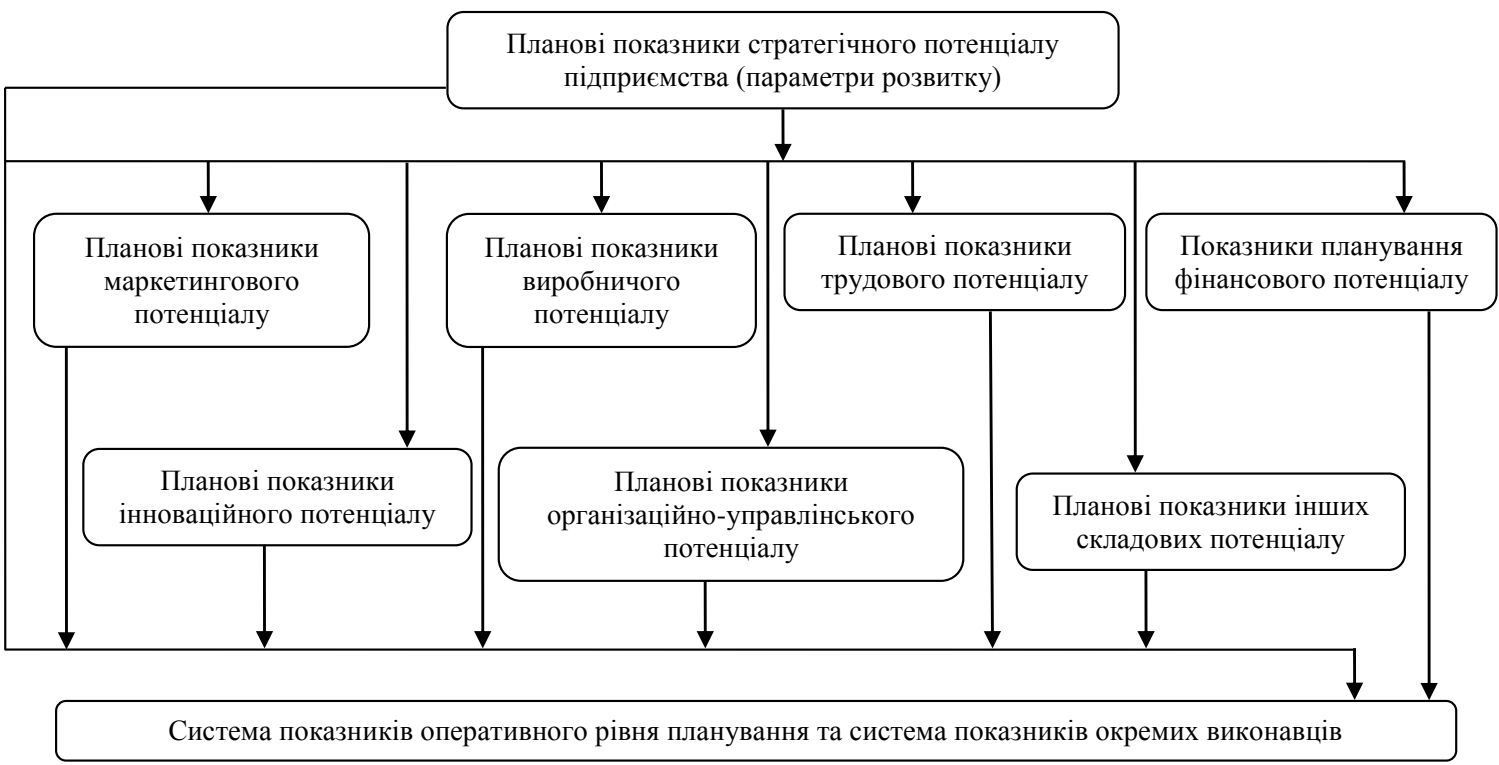

Рис. 2. Укрупнена модель збалансованої системи показників планування потенціалу підприємства [1] 
Професор А.Є. Воронкова зауважує, що використання показників, які характеризують потенціал у процесах управління ним, визначає доцільність їх позначення як «параметри» - вони відображають якісний характер, ознаку потенціалу як об’єкта управління (рівень, стан, спрямованість, достатність тощо) [17, с. 128]. «Параметр» - це теж показник, однак цей термін визначає його подальше використання через його зміни з метою впливу на стан досліджуваного об'єкта [18]. Тому, на нашу думку, систему показників планування стратегічного потенціалу можна розглядати як систему стратегічних параметрів, критеріїв та індикаторів розвитку, які визначаються цілями підприємства, його положенням на ринку, в галузі, і які $є$ основою для розробки функціональних планів розвитку потенціалу, що забезпечують реалізацію поставлених цілей і завдань.

Стратегічні карти є зрозумілим форматом для всіх учасників управлінського процесу, мобілізуючи їхні зусилля на досягнення цілей. Карта інформує менеджерів і персонал підприємства про стратегічні цілі, загострюючи увагу на діяльності, яка мотивована не тільки поточними цілями, а й стратегічними. Підприємства мають задовольняти своїх споживачів, клієнтів, у всіх підприємств є свої внутрішні бізнеспроцеси і встановлена практика господарювання; менеджери і працівники прагнуть отримати винагороду за виконану роботу і реалізацію свого творчого потенціалу тощо. Базова модель збалансованої системи показників підприємства (карта показників) з прикладами за кожною із чотирьох перспектив наведена на рисунку 3.

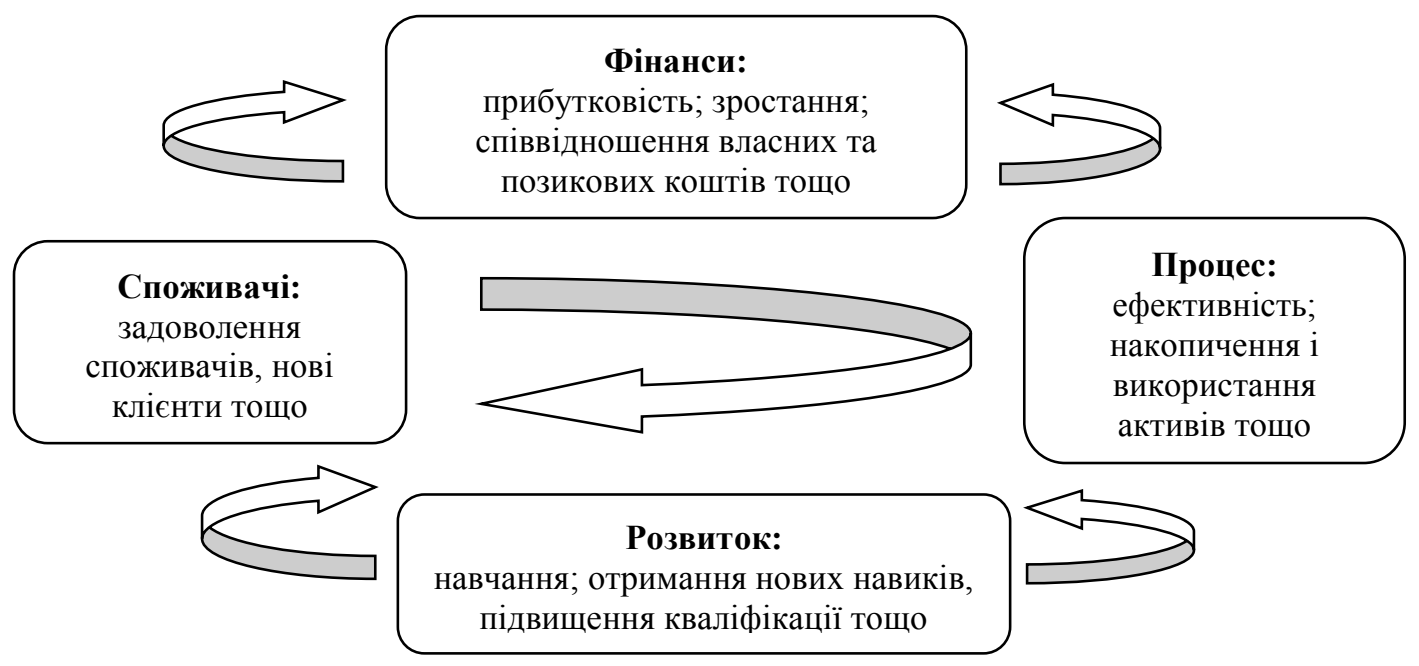

Рис. 3. Базова модель збалансованої системи показників з прикладами за кожною із чотирьох перспектив [16, с. 17$]$

У зазначеній моделі не відображено причинно-наслідкові зв'язки за визначеними аспектами діяльності, не існує розмежування за ієрархічними рівнями управління. Оскільки стратегічна карта $\epsilon$ логічним описом бізнесу з використанням параметрів за визначеними перспективами діяльності, то зв'язок між ними має відображатися в обов'язковому порядку.

Стратегічні цілі та показники можуть визначатися окремо для кожного підрозділу залежно від функціонального призначення. Стратегічні карти можуть також складатися окремо для підрозділів, тоді буде витримано не тільки бізнес-логіку майбутніх процесів, а й створено синергетичний ефект.

«Збалансована система показників - це назва методу, що використовується для опису стратегій $\mathrm{i}$ перевірки успішності досягнення цих цілей різними підрозділами. Цю модель можна порівняти із світлофором, де зелений колір означає, що робота проходить як слід і цілі будуть досягнуті. Жовтий - це сигнал попередження. Червоний означає, що все йде не так як потрібно і необхідно вжити радикальних дій, щоб досягнути успіху. ... системи преміювання повинні діяти як необхідний двигун для забезпечення цих додаткових умов» [16, с. 96]. Тож збалансована система планових показників вдало вбудовується в систему управління плануванням на підприємстві, оскільки всі чотири основні функції управління (планування, організація, мотивація і контроль) є необхідними у впровадженні та реалізації цієї системи.

У різних країнах стратегічні карти використовують також в діяльності органів центральної влади та місцевого самоврядування. Всі чотири перспективи стратегічної карти можуть бути збережені та інтерпретовані відповідно до цілей та завдань діяльності таких організацій. Наприклад, перспектива «фінанси» передбачає визначення фінансових потреб організації для задоволення суспільних потреб відповідно до місії організації. Перспектива «клієнт» - це зовнішня перспектива, яка описує успішність організації у взаємодії між заінтересованими сторонами громадянського суспільства тощо. Перспектива «процес» - кожен структурний підрозділ, кожен відділ має брати участь у реалізації 
стратегії. Жодна ключова зміна, починаючи з внутрішніх процесів будь-якої організації, не може бути ефективною i добре керованою. Як i при створенні будь-якої стратегічної карти, керівники некомерційної організації мають бути зацікавлені в якісному виконанні стратегічних завдань. Перспектива «розвиток» - як і в будь-якому бізнесі некомерційним організаціям необхідно впроваджувати нові технології, нові знання та навички.

Ще одна важлива річ - це зв'язок між картами показників різних структурних підрозділів. Це питання логіки. Варто використовувати одні й ті ж показники для вимірювання, однакові за своєю суттю. Але це не означає, що такий показник є обов'язковим для всіх рівнів ієрархії. Додавання результатів як математичний вираз не завжди єдиний спосіб узагальнення, оскільки розробка цілей нижчого рівня ієрархії відповідно до загальної стратегії потребує обдумування, розуміння і точно не є математичною задачею. 3 цим пов'язано також формулювання цілей за часом і забезпечення стимулювання. Важливо детально аналізувати, в яких випадках показники карти повинні описувати ситуацію в локальному підрозділі, а в яких випадках оцінювати умови, що $є$ результатом спільної діяльності 3 іншими структурними підрозділами. При вбудовуванні карти показників у систему преміювання важливо, щоб дані були достовірними та надійними.

Висновки. Отже, оптимальний набір показників, включених до системи, має задовольняти потреби в даних усіх користувачів інформації - учасників управлінського процесу і визначається суб'єктом господарювання самостійно. Проте концепція ЗСП настільки широко використовується та інтерпретується, що на сьогодні складно навіть пропонувати так званий «нормативний» набір показників. Але порівняно із іншими інструментами опису організаційних стратегій, ЗСП має дві особливості. Перше - це простий зручний формат стратегічної карти, описаний системою показників, для кожної із перспектив діяльності: фінансової, споживацької або клієнтської, внутрішніх бізнеспроцесів, а також навчання та розвиток. Друге - правильно та грамотно розроблена карта показників відображає стратегічну логіку причинно-наслідкових зв'язків між поточною діяльністю та довгостроковим успіхом. Карти показників переводять стратегію в терміни повсякденної і усвідомленої діяльності працівників організації.

\section{Список використаної літератури:}

1. Тарасюк Г.М. Методологічні підходи до формування збалансованої системи планових показників в концепції планування потенціалу підприємств харчової промисловості / Г.М. Тарасюк // Вісник Житомирського державного технологічного університету. Серія : Економічні науки. - 2010. - Вип. 1. C. $225-233$.

2. Каплан P. Организация ориентированная на стратегию. Как в новой бизнес-среде преуспевают организации, применяющие Сбалансированную систему показателей / Р.Каплан, Д.Нортон. - Пер. с англ. М. : Олимп-Бизнес, 2004. - 392 с.

3. Каплан Р. Сбалансированная система показателей. От стратегии к действию / Р.Каплан, Д.Нортон. - Пер. с англ. - М. : Олимп-Бизнес, 2003. - 214 с.

4. Каплан Р. Стратегические карты. Трансформация нематериальных активов материальные результаты / Р.Каплан, Д.Нортон. - Пер. с англ. - М. : Олимп-Бизнес, 2005. - 482 с.

5. Панели индикаторов как инструмент управления: ключевые показатели эффективности, мониторинг деятельности, оценка результатов / Пер. с англ. Уэйн У.Эккерсон. - М. : Альпина Бизнес Букс, 2007. - 396 с.

6. Рамперсад $X$. Универсальная система показателей: как достигать результатов, сохраняя целостность / Х.Рамперсад. - Пер. с англ. - 3-е изд. - М. : Альпина Бизнес Букс, 2006. - 352 с.

7. Хан Дитгер ПиК. Стоимостно-ориентированные концепции контроллинга / Хан Дитгер, Хунгенберг Харальд. - Пер. с нем. под ред. Л.Г. Головача, М.Л. Лукашевича и др. - М. : Финансы и статистика, 2005. $928 \mathrm{c}$.

8. Bramsemann R. Handbuch Controlling: Methoden und Techniken / R.Bramsemann. - Munchen : Wien; Hanser, 1990.

9. Сайт школи стратегічного планування [Електронний ресурс]. - Режим доступу : http://www.stplan.ru/.

10. Баланс между стратегией и контролем / Нильс-Горан Олве, Карл-Йохан Петри, Жан Рой, Софи Рой. - Пер. с англ. Е.Колотвиной / Под. ред. У.Добровольского. - СПб. : Питер, 2005. - 320 с.

11. Кизим М.О. Збалансована система показників : монографія / М.О. Кизим, А.А. Пилипенко, В.А. Зінченко.-Х. : ВД «НЖЕК», 2007. - 192 с.

12. Хайлук С.O. Практичні аспекти застосування контролінгу в системі управління фінансами молокопродуктового холдингу / С.О. Хайлук // Актуальні проблеми економіки. - 2007. - № 3 (69). - С. 144 154.

13. Тарасюк Г.М. Методологічні основи формування системи планових показників / Г.М.Тарасюк // Проблеми статистики: зб. наук. праць Науково-технічного комплексу статистичних досліджень Держкомстату України. - К. : ДП «Інформаційно-аналітичне агентство», 2007. - Вип. 8. - С. 98-104.

14. Тарасюк Г.М. Управління плануванням діяльності підприємства: теоретичні та практичні аспекти : монографія / Г.М. Тарасюк. - Житомир : ЖДТУ, 2010. - 290 с.

15. Тарасюк Г.М. Планова діяльність як системний процес управління підприємством : монографія / Г.М. Тарасюк. - Житомир : ЖДТУ, 2006. - 469 с. 
16. Діагностика стану підприємства: теорія і практика : монографія / А.Е. Воронкова, Р.З. Вечерковскі, Д.К. Воронков та ін. - За заг. ред. проф. А.Е. Воронкової. - Х. : ВД «ІНЖЕК», 2006. - 448 с.

17. Большой экономический словарь / Под ред. А.И. Азрилияна. - 5-е изд., доп. и перераб. - М. : Ин-т новой экономики, 2002. - 1280 с.

\section{References:}

1. Tarasyuk, G.M. (2010), «Metodologichni pidkhodi do formuvannya zbalansovanoï sistemi planovikh pokaznikiv v kontseptsiï planuvannya potentsialu pidprijemstv kharchovoï promislovosti», Visnik Zhitomirs'kogo derzhavnogo tekhnologichnogo universitetu, Seriya Ekonomichni nauki, Issue 1, pp. 225-233.

2. Kaplan, R. and Norton, D. (2004), Organizatsiya orientirovannaya na strategiyu. Kak v novoy biznes-srede preuspevayut organizatsii, primenyayushchie Sbalansirovannuyu sistemu pokazateley, translated from english, Olimp-Biznes, Moskva, 392 p.

3. Kaplan, R. and Norton, D. (2003), Sbalansirovannaya sistema pokazateley. Ot strategii $k$ deystviyu, translated from english, Olimp-Biznes, Moskva, 214 p.

4. Kaplan, R. and Norton, D. (2005), Strategicheskie karty. Transformatsiya nematerial'nykh aktivov material'nye rezul'taty, translated from english, Olimp-Biznes, Moskva, $482 \mathrm{p}$.

5. Paneli indikatorov kak instrument upravleniya: klyuchevye pokazateli effektivnosti, monitoring deyatel'nosti, otsenka rezul'tatov (2007), translated by Ueyn U.Ekkerson, Al'pina Biznes Buks, Moskva, 396 p.

6. Rampersad, Kh. (2006), Universal'naya sistema pokazateley: kak dostigat' rezul'tatov, sokhranyaya tselostnost', translated from English, 3nd ed., Al'pina Biznes Buks, Moskva, 352 p.

7. Khan, Ditger and Khungenberg, Kharal'd (2005), PiK. Stoimostno-orientirovannye kontseptsii kontrollinga, translated from German, in L.G.Golovach, M.L. Lukashevich and other (ed.), Finansy i statistika, Moskva, 928 p.

8. Bramsemann, R. (1990), Handbuch Controlling: Methoden und Techniken, Wien, Hanser, Munchen.

9. Sayt shkoli strategichnogo planuvannya, [Online], available at: http://www.stplan.ru

10. Olve, Nil's-Goran, Petri, Karl-Yokhan, Roy, Zhan and Roy, Sofi (2005), Balans mezhdu strategiey i kontrolem, translated by E.Kolotvinoy, in U.Dobrovol'skyi (ed.), Piter, Sankt-Peterburg, 320 p.

11. Kizim, M.O., Pilipenko A.A. and Zinchenko V.A. (2007), Zbalansovana sistema pokaznikiv, monografiya, VD «INZhEK», Harkiv, 192 p.

12. Khayluk, S.O. (2007), «Praktichni aspekti zastosuvannya kontrolingu v sistemi upravlinnya finansami molokoproduktovogo kholdingu», Aktual'ni problemi ekonomiki, No. 3 (69), pp. 144-154.

13. Tarasyuk, G.M. (2007), «Metodologichni osnovi formuvannya sistemi planovikh pokaznikiv», Problemi statistiki, zb. nauk. prats' Naukovo-tekhnichnogo kompleksu statistichnikh doslidzhen' Derzhkomstatu Ukrainy, DP «Informatsiyno-analitichne agentstvo», Kyiv, Issue 8, pp. 98-104.

14. Tarasyuk, G.M. (2010), Upravlinnya planuvannyam diyal'nosti pidpriєmstva: teoretichni ta praktichni aspekti, monografiya, ZhDTU, Zhitomir, $290 \mathrm{p}$.

15. Tarasyuk, G.M. (2006), Planova diyal'nist' yak sistemniy protses upravlinnya pidpryjemstvom, monografiya, ZhDTU, Zhitomir, $469 \mathrm{p}$.

16. Voronkova, A.E., Vecherkovski, R.Z., Voronkov, D.K. and other (2006), Diagnostika stanu pidpryjemstva: teorija i praktika, monografija, in A.E. Voronkova (ed.), VD «INZhEK», Harkiv, 448 p.

17. Bol'shoj jekonomicheskij slovar', in A.I. Azrilijan (ed.), 5nd ed., dop. i pererab, In-t novoj jekonomiki, Moskva, $1280 \mathrm{p}$.

Тарасюк Галина Миколаївна - доктор економічних наук, професор, декан факультету бізнесу та сфери обслуговування Державного університету «Житомирська політехніка».

Наукові інтереси:

- проблеми теорії та практики планування діяльності суб’єктів господарювання;

- управління проектами;

- проблеми менеджменту суб'єктів господарювання.

E-mail: galinatar@ukr.net.

Донець Олександр Андрійович - магістрант за спеціальністю «Менеджмент» факультету бізнесу та сфери обслуговування Державного університету «Житомирська політехніка»

Наукові інтереси:

- проблеми менеджменту суб'єктів господарювання.

E-mail: zh_centrmce@ukr.net.

Горшкова Людмила Олександрівна - старший викладач кафедри менеджменту і туризму Державного університету «Житомирська політехніка».

Наукові інтереси:

- проблеми розвитку туризму та готельно-ресторанного бізнесу;

- проблеми менеджменту суб'єктів господарювання.

E-mail: lydun4ik1979@ukr.net. 